\title{
What Audience, What Labour? A Review of the 2015 Dallas Smythe Memorial Lecture by Oscar Gandy
}

\section{Byron Hauck}

School of Communication

Simon Fraser University

Simon Fraser University's motto is "Engage the World". Few events are a better platform to see how this concept is put into action than at the year-end capstone presentations of SFU and the Communication University of China's joint Double MA Degree program in Global Communication. This year's presentations were conducted by the program's second cohort of students who, having submitted their work to the library, are now beginning their second and final year in China. The vast array of places, issues and concepts touched upon in their collective work identify how 'the global' is more than just geography in the way that communication is more than just what is said. These critical investigations hint at the ways in which the students move past merely engaging academic audiences by focusing on addressing the needs of the many communities that form our global village.

The general themes which this year's cohort developed were: examining the communication of gender, critiquing security practices and mapping changes in culture as worlds collide in the process of globalization. Following Arif Dirlik's (2007) critique of the convergence theories of globalization, the students presented works arguing for changes in the status quo. They accomplished this through the pedagogical practice of reflecting upon their own lived experiences, reflexively addressing the axioms which position current power relationships and recursively grounding their findings in the multiple theoretical bodies they encountered over their year at SFU.

Kirsten Berry kicked off the day with her critical evaluation of how Canadian news media frames terrorism. She based her project on her own experience growing up in the post 9-11 news media world to challenge the image which such experience had left her and her fellow Canadians with. Identifying how race, nationality and violence intersect in the framing of international security stories Kirsten concluded that the news media has contributed to legitimating new anti-terror government powers and legislations.

Wei Huang kept the focus on the media but shifted the discussion to a comparative study of entertainment labour in China. She contrasted the socialist ideals associated with art workers in Mao's era with the competitive field of contemporary music reality shows. Her transcultural political economic critique investigated the multiple penetrations of commodification that has accompanied the change in both the presentation of performances as well as the general spread of celebrity culture amongst society as a whole.

Lucia Inyang moved this discussion of media to the evolving themes of feminism in Nigerian literature. Through the novels Efuru, Second Class Citizen and Purple Hibiscus, Luica mapped the growing space taken up by women in Nigeria and provided a meta-discussion on the use of fictional literature to inspire further social changes in her home country.

The medium of the human body was the subject of Beatrice Chao's presentation. With a particular focus on the commodification of cosmetic alterations, her discussion on the differences in global practices of plastic surgery opened a discussion on the attempted homogeneity of market values in comparison to the dynamic heterogeneity of aesthetic values.

Shawn Jones went from the practices of the media into its regulation with a radical examination of the relationship the Canadian Radio-television and Telecommunications Commission (CRTC) has with gay pornography. Beginning with the debate of the seriousness of the CRTC's 2014 warning to three Canadian adult television channels to conform to Canadian content regulations, Shawn defended the presentation of gay sex as a Canadian cultural product. A compelling argument that 
came through Shawn's presentation is that gay youth have few avenues in which to see and learn about the physicality of their sexuality. He used this point to recognize the CRTC's treatment of gay porn as a cultural product as a victory in the continuing de-marginalization of a homosexual life.

Changing the theme from the media to the use of messages, Amanda Liao critiqued the leading role of liberal feminism in the War on Terror. Positing liberal feminism as one neglecting race, class and history, Amanda extended Suneria Thobani's (2008) argument on how this discourse enables imperialistic military interventions by universalizing western morality.

Hatty Liu took an adventurous swing at the myth-making of global news media critiquing the ways in which western journalists contribute to a negative frame of China. Hatty built off of Roland Barthes' (1972) landmark work on myth as a form of speech which destroys history and posits accounts as universal across time and place. Using the stories of China's recent stock market crisis as a case study for her investigation, Hatty found conclusions about the presumed ineptness of the Chinese government and society in dealing with the crisis to be based more on general parables against betraying the ideals of the free market rather than on any understanding of China's own context.

Yu Song wrapped up the event by taking current news media debates around Chinese public square dancing to the historic beginnings of public dance in China. Through this history Song identified how public dancing has been used to reinforce the 'politics of the day' from Imperial through to Republican, Maoist and Reform China. Song identified China's contemporary domestic debate over public square dancing as an ideological clash between socialist sentiments represented in the form of the dancing and use of public space against the government's encouragements of harmonizing it with market practices and local struggles over the privatization of space.

Song's delve into history reminds me of the $13^{\text {th }}$ century Franciscan friar Roger Bacon's claim that half of knowing the world is asking the right questions. The presentations from this cohort of students demonstrated the importance of that insight with their informed and focused questioning into current global communication issues. In the proper fashion of knowledge building the answers they provided alongside their questions spark the rest of us to move out of contentment and inquire further. Truly their minds engaged the world and their investigations will continue to touch others as they move to China and develop their projects further.

\section{References}

Barthes, R. (1972). Mythologies. (Jonathan Cape Ltd. Trans.). USA: Farrar, Straus and Giroux.

Dirlik, A. (2007) Global Modernity: Modernity in the Age of Global Capitalism. USA: Paradigm Publishers.

Thobani, S (2008). Gender and empire: Veilomentaries and the War on Terror. In Chakravarty, P and Zhao, Y (eds.), Global Communications: Towards a Transcultural Political Economy (pp. 219242) USA: Rowman \& Littlefield Publishers Inc. 